\title{
MELANIZING ACTIVITY OF SEMEN AND ITS RELATION TO LIVE SPERMATOZOA OF BULLS, GOATS AND RAMS
}

\author{
D. P. MUKHERJEE \\ Division of Animal Genetics, Indian Veterinary Research Institute, Izatnagar, India
}

(Received 12th Fune 1963)

\begin{abstract}
Summary. Melanizing activity of semen varied between males and between ejaculates of the same male. Samples of semen with yellow colour showed stronger melanizing activity than other samples. The percentage of live spermatozoa found after different levels of temperature shock was uniformly less in semen with strong melanizing activity than in semen with weak melanizing activity. The observed variation in live spermatozoa after shock treatments followed a curvilinear trend with slopes varying among the species studied.
\end{abstract}

\section{INTRODUCTION}

Melanizing activity of rabbit semen when supplied with the substrate 'dopa' (dihydroxyphenylalanine) was reported by Beatty (1956). The intensity of melanization, however, was correlated with the depth of coat colour of the male from which the semen was obtained. It was also reported by Beatty that semen of black rabbits was yellow in colour and that the yellow semen gave intense colour reaction with 'dopa' solution. As the difference in coat colour of the rabbits used in the experiment was due to the difference between genes at the albino locus, it appeared that the difference in the intensity of colour reaction and the presence of yellow colour in semen of black rabbits was due to the difference in genes. Chang (1959) observed that rabbit semen collected by means of an artificial vagina was frequently contaminated with urine, specially when the temperature of the vagina was high. Such urine-contaminated semen was yellow in colour. Whatever the cause (hereditary or acquired) may be for the presence of yellow colour in the semen of rabbits, the presence of yellow pigment is not uncommon in the semen of farm animals. It was, therefore, considered worth while to ascertain whether the semen of bulls, goats and rams showed melanizing activity and, if so, whether the activity was correlated in any way with the coat colour of the male, the colour of the semen produced and/or the proportion of living spermatozoa before and after various levels of cold shock in semen.

\section{MATERIALS AND METHODS}

For the experiment four Hariana bulls, six goats and eight Bikaneri rams were used. The bulls had the coat colour of the breed as described by Kaura (1957). 
Two of the bulls (Nos. 1030 and 970 ) produced predominantly yellow semen. The other two bulls (Nos. 1064 and 793) occasionally produced yellow semen prior to their use in the present experiment. Three of the bulls were approximately 7 years old and Bull 793 was 10 years old. Five semen samples (one sample per day) were obtained from each bull by means of an artificial vagina, and tested for melanizing activity. Five of the goats were of local type and one was of Barberi breed. The coat colour of the goats was either black with white patches or white with black or brown patches. Twelve semen samples (one sample per day) were obtained from each goat by means of an artificial vagina, and tested for melanizing activity. The rams had the coat colour of the breed (Bikaneri) as described by Kaura (1957). Their age varied between $4 \frac{1}{2}$ and 5 years except for Rams 5 and 9, which were 8 and $1 \frac{1}{2}$ years, respectively. A variable number of samples of semen were obtained from each ram and tested for melanizing activity.

For testing melanizing activity, a sample of semen was diluted with normal saline solution immediately after collection. For bull semen, the dilution was 1 in 50 and for goat and ram semen 1 in 100. From the diluted semen, $9 \mathrm{ml}$ was taken in a test tube, $1 \mathrm{ml}$ of $0.1 \%$ 'dopa' was added and it was left at room temperature $\left(20\right.$ to $25^{\circ} \mathrm{C}$ ) for $6 \mathrm{hr}$. Usually within $3 \mathrm{hr}$ colour developed, but it was graded after $6 \mathrm{hr}$ according to the scale described by Beatty (1956). The relation between the melanizing activity of semen and the proportion of living spermatozoa after varying levels of cold shock, was studied by the following method:

Some of the semen immediately after collection was withdrawn and tested for melanizing activity and the rest was used to study the effect of various levels of temperature shock on the proportion of living spermatozoa according to the method described by Hancock (1951). The sample was held in a water bath at $30^{\circ} \mathrm{C}$, and stained for 2 min with nigrosin-eosin maintained at a series of temperature levels ranging from 0 to $30^{\circ} \mathrm{C}$. The composition of the stain and the method of preparing the slides were as described by Mukherjee \& Dott (1960). From the mixture of semen and stain, four slides were made for bull and two slides for goat and ram semen. Sixteen bull, eighteen goat and twenty-two ram semen samples were tested both for melanizing activity and proportion of living spermatozoa at seven temperature levels. The slides were coded before they were examined for the percentage of unstained (living) spermatozoa. One hundred spermatozoa on each slide were selected at random for examination. The percentage figures so obtained were used in the analysis.

\section{RESULTS}

In Table 1, the results of the study on the melanizing activity of semen from the three species of animals are summarized. It will be seen from the Table that the melanizing activity not only varied among animals of the same species, but also among samples from the same animal. The intensity of colour did not exceed ++ . It may be mentioned that the seminal plasma (free from spermatozoa) of semen samples with melanizing activity varying from + to ++ also gave colour reaction when supplied with dopa solution. Semen samples with yellow 
colour showed stronger melanizing activity than samples without the yellow colour.

It was concluded that the proportion of unstained (viable) spermatozoa in semen with and without melanizing activity could not be studied, as none of the animals gave semen samples which were consistently free from melanizing activity. At best, the study could be made in samples showing strong, + to ++ , and weak, 0 to $(+)$, melanizing activity. Semen samples from Bulls 1030 and 970 could be grouped as strongly, and those from Bulls 1064 and 793 as weakly melanizing. Grouping of goat and ram semen samples on the basis of animals

TABLE 1

MELANIZING AGTIVITY OF SEMEN SAMPLES FROM BULLS, GOATS AND RAMS

\begin{tabular}{|c|c|c|c|c|c|c|}
\hline \multirow{2}{*}{\multicolumn{2}{|c|}{ Animal }} & \multirow{2}{*}{$\begin{array}{c}\text { No. } \\
\text { samples } \\
\text { tested }\end{array}$} & \multicolumn{4}{|c|}{ Melanizing activity } \\
\hline & & & 0 & $(+)$ & + & ++ \\
\hline $\begin{array}{c}\text { Hariana } \\
\text { bull }\end{array}$ & $\begin{array}{r}1030 \\
970 \\
793 \\
1064\end{array}$ & $\begin{array}{l}5 \\
5 \\
5 \\
5\end{array}$ & $\begin{array}{l}\overline{-} \\
\overline{4} \\
-\end{array}$ & $\begin{array}{l}- \\
\overline{4}\end{array}$ & $\begin{array}{l}\overline{1} \\
1 \\
1\end{array}$ & $\begin{array}{l}5 \\
4 \\
- \\
-\end{array}$ \\
\hline Goat & $\begin{array}{l}1 \\
2 \\
3 \\
4 \\
6 \\
7\end{array}$ & $\begin{array}{l}12 \\
12 \\
12 \\
12 \\
12 \\
12\end{array}$ & $\begin{array}{l}\overline{-} \\
\overline{1} \\
\overline{1} \\
2\end{array}$ & $\begin{array}{l}- \\
\overline{6} \\
2 \\
6 \\
3\end{array}$ & $\begin{array}{l}5 \\
1 \\
5 \\
7 \\
1 \\
4\end{array}$ & $\begin{array}{r}7 \\
11 \\
-3 \\
4 \\
3\end{array}$ \\
\hline $\begin{array}{l}\text { Bikaneri } \\
\text { ram }\end{array}$ & $\begin{array}{r}3 \\
4 \\
5 \\
6 \\
7 \\
8 \\
9 \\
10\end{array}$ & $\begin{array}{r}12 \\
12 \\
11 \\
13 \\
12 \\
10 \\
7 \\
6\end{array}$ & $\begin{array}{l}4 \\
7 \\
1 \\
5 \\
- \\
2 \\
1 \\
-\end{array}$ & $\begin{array}{l}3 \\
3 \\
4 \\
6 \\
8 \\
3 \\
1 \\
1\end{array}$ & $\begin{array}{l}3 \\
1 \\
3 \\
1 \\
2 \\
2 \\
4 \\
3\end{array}$ & $\begin{array}{l}2 \\
1 \\
3 \\
1 \\
2 \\
3 \\
1 \\
2\end{array}$ \\
\hline
\end{tabular}

was not possible as they produced semen which gave varying grades of colour reaction. Semen samples from these animals were, therefore, grouped strictly on the basis of colour reaction as shown in Table 2.

Melanizing activity of semen and the mean percentage of unstained spermatozoa at different levels of temperature shock in semen are given in Table 3. The number of semen samples with different grades of colour reaction in the two groups are also given. For example, out of eight semen samples from bulls in the strong melanizing group, seven were ++ and one was + . It will be seen from the table that the mean percentage of unstained spermatozoa at all temperature levels was less in the strong than in the weak melanizing group. In both the groups, the mean percentage decreased with the increased temperature difference between semen and stain. Differences observed in the percentage of unstained spermatozoa were studied in the analysis of variance, the details of which are given in Tables 4 and 5, where the figures are rounded off to the nearest whole number. 
TABLE 2

GROUPING OF SEMEN SAMPLES FROM GOATS AND RAMS

\begin{tabular}{cc|c|c}
\hline \multirow{2}{*}{ Animal } & \multicolumn{2}{|c}{ No. samples } \\
\cline { 2 - 4 } & & sMG & WMG \\
\hline Goat & 1 & 2 & 1 \\
& 2 & 3 & - \\
& 3 & - & 3 \\
& 4 & 2 & 1 \\
& 6 & - & 3 \\
& 7 & 2 & 1 \\
\hline Ram & 3 & 2 & 3 \\
& 4 & 1 & 3 \\
5 & 2 & - \\
& 6 & 1 & 2 \\
7 & 1 & 2 \\
8 & 3 & - \\
9 & - & 1 \\
10 & 1 & - \\
\hline
\end{tabular}

SMG = Strong melanizing group; WMG $=$ Weak melanizing group.

TABLE 3

MEAN PERGENTAGE OF UNSTAINED SPERMATOZOA OF BULLS, GOATS AND RAMS AT DIFFERENT LEVELS OF TEMPERATURE SHOCK IN SEMEN

\begin{tabular}{|c|c|c|c|c|c|c|c|c|}
\hline \multirow{2}{*}{ Animal } & \multirow{2}{*}{ Group } & \multicolumn{7}{|c|}{ Percentage of unstained spermatozoa at: } \\
\hline & & $30^{\circ} \mathrm{C}$ & $25^{\circ} \mathrm{C}$ & $20^{\circ} \mathrm{C}$ & $15^{\circ} \mathrm{C}$ & $10^{\circ} \mathrm{C}$ & $5^{\circ} \mathrm{C}$ & $0^{\circ} \mathrm{C}$ \\
\hline $\begin{array}{l}\text { Bull } \\
(970 \text { and } 1030)\end{array}$ & $\frac{\text { SMG }}{1}+\frac{++}{7}$ & $74 \cdot 9$ & $76 \cdot 1$ & $74 \cdot 5$ & $69 \cdot 3$ & $66 \cdot 9$ & $64 \cdot 0$ & $54 \cdot 6$ \\
\hline $\begin{array}{l}\text { Bull } \\
\text { (793 and 1064) }\end{array}$ & $\frac{0}{3}+\frac{(+)}{5}$ & $78 \cdot 3$ & $77 \cdot 7$ & $78 \cdot 3$ & $71 \cdot 6$ & $73 \cdot 3$ & $69 \cdot 4$ & $59 \cdot 8$ \\
\hline Goat & $\frac{t}{1}+\frac{+t}{8}$ & $70 \cdot 9$ & $73 \cdot 1$ & $67 \cdot 4$ & $67 \cdot 7$ & $56 \cdot 6$ & $50 \cdot 5$ & $45 \cdot 5$ \\
\hline Goat & $\frac{0}{2}+\frac{(+)}{7}$ & $82 \cdot 1$ & $80 \cdot 1$ & $76 \cdot 1$ & $73 \cdot 6$ & $67 \cdot 2$ & $60 \cdot 4$ & $52 \cdot 1$ \\
\hline Ram & $\begin{array}{l}\text { SMG } \\
\frac{+t}{11}\end{array}$ & $59 \cdot 0$ & $56 \cdot 8$ & $56 \cdot 0$ & $57 \cdot 7$ & $47 \cdot 6$ & $34 \cdot 0$ & $30 \cdot 0$ \\
\hline Ram & $\frac{0}{5}+\frac{\text { WMG }}{6}$ & $78 \cdot 3$ & $78 \cdot 3$ & $77 \cdot 7$ & $73 \cdot 1$ & $66 \cdot 0$ & $58 \cdot 9$ & 39.1 \\
\hline
\end{tabular}

SMG $=$ Strong melanizing group; WMG $=$ Weak melanizing group. 
Details of analyses of variance of unstained bull spermatozoa are given in Table 4. Mean squares between groups and between bulls were tested against mean squares between samples within bulls and they were found to be statistically not significant.

The details of analyses of unstained goat and ram spermatozoa are given in Table 5 . In the analyses, variations between samples and not between animals

TABle 4

ANALYSIS OF VARIANCE OF UNSTAINED BULL SPERMATOZOA

\begin{tabular}{l|r|c}
\hline \multicolumn{1}{c|}{ Source of variation } & & $\begin{array}{c}\text { Mean } \\
\text { squares }\end{array}$ \\
\hline Between groups & d.f. & 1808 \\
Between bulls within groups & 1 & 5062 \\
Between semen samples within bulls & 12 & $3983^{*}$ \\
Between treatments & 6 & $3246^{*}$ \\
Between groups $\times$ treatments & 6 & 47 \\
Between bulls $\times$ treatments & 12 & 91 \\
Error & 72 & 107 \\
Between slides & 336 & 40 \\
\hline
\end{tabular}

$* P<0.001$.

TABLE 5

ANALYSIS OF VARIANCE OF UNSTAINED GOAT AND RAM SPERMATOZOA

\begin{tabular}{|c|c|c|c|c|}
\hline \multirow{2}{*}{ Source of variation } & \multicolumn{2}{|c|}{ Goat } & \multicolumn{2}{|c|}{ Ram } \\
\hline & d.f. & $\begin{array}{c}\text { Mean } \\
\text { squares }\end{array}$ & d.f. & $\begin{array}{c}\text { Mean } \\
\text { squares }\end{array}$ \\
\hline $\begin{array}{l}\text { Between groups } \\
\text { Between semen samples with group } \\
\text { Between treatments } \\
\text { Between groups } \times \text { treatments } \\
\text { Between samples } \times \text { treatments } \\
\text { Error }\end{array}$ & $\begin{array}{r}1 \\
16 \\
6 \\
6 \\
96 \\
126\end{array}$ & $\begin{array}{l}4629 \\
1935^{*} \\
4202^{*} \\
39 \\
202^{*} \\
84\end{array}$ & $\begin{array}{r}1 \\
20 \\
6 \\
6 \\
120 \\
154\end{array}$ & $\begin{array}{r}26706^{*} \\
1085^{*} \\
7487^{*} \\
294^{*} \\
135^{*} \\
38\end{array}$ \\
\hline
\end{tabular}

were considered. In the ram, but not in the goat, group treatment interaction was significant. To test the significance between groups, mean variance of semen samples within groups was used as the error term. The results showed that variations between groups was significant in the ram, but not in the goat. Mean square between groups in goat was much higher than any other mean squares studied.

On the whole, the analyses revealed that in spite of considerable variation between groups in the three species, these variations were not significant except in the ram. This might be due to the conspicuous difference between samples of the two groups of rams. In the strongly melanizing group, all the samples were ++ and in the weakly melanizing group the samples varied from 0 to $(+)$. It was sometimes difficult to make visual appraisal between $(+)$ and + , and the method employed might not be sensitive enough to bring out the 
differences without fail, so that samples within this narrow range might not have been effectively segregated into two groups. As a result, differences between groups in bulls and goats were not as high as in rams and were not statistically significant. Nevertheless, it is apparent from Table 3 that in the three species the mean percentage of unstained spermatozoa at all temperature levels was less in the strong than in the weak melanizing group. Variations in the percentage of unstained spermatozoa in the two groups at different levels of

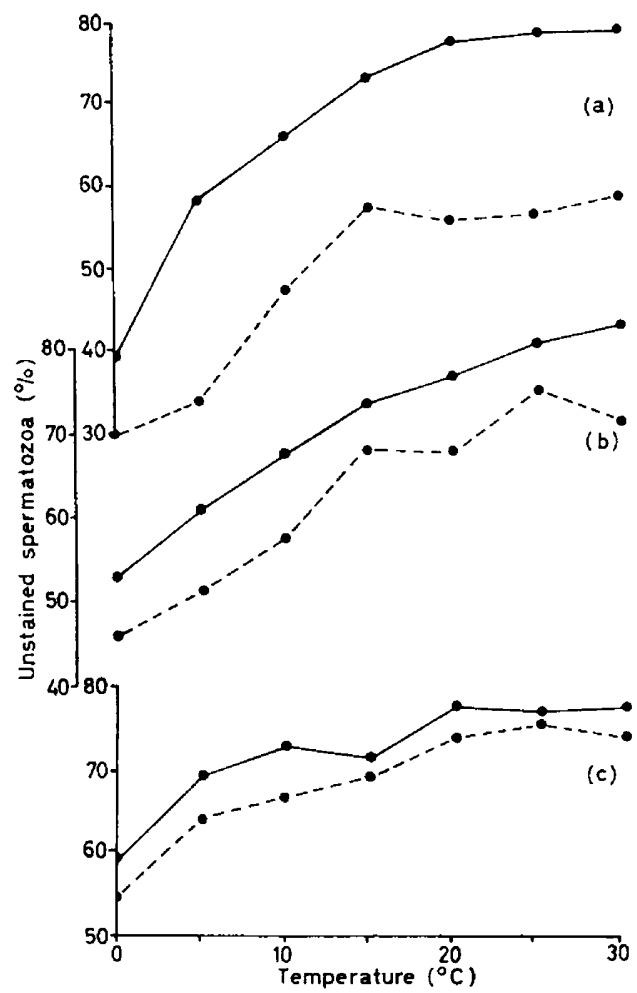

Text-FIG. 1. Percentage unstained spermatozoa at various temperatures. (a) Ram; (b) goat; (c) bull. —W Weak melanizing group; - . . - strong melanizing group.

temperature shock are graphically represented in Text-fig. 1. It appears that the graphs are curvilinear and that the form of the slopes is different in different species. Within a given species it looks as if the same curve would apply to both the strong and the weak melanizing group.

\section{DISCUSSION}

Definite melanizing activity of bull, goat and ram semen was observed in the present experiment. The intensity of melanization, however, did not exceed ++ . Beatty (1956) observed intensity of colour as high as +++ to ++++ in semen samples of black or nearly black rabbits. Beatty also observed the absence of melanizing activity in semen samples of albino rabbits. As true albinism is a rarity in farm animals, it is expected that semen of farm animals may not be free from the melanizing activity. That it is so has been fully 
established in the present experiment. Semen samples from no single animal were constantly free from melanizing activity. The intensity of melanization, however, varied among bulls and rams with no conspicuous difference in their coat colour. The goats were of various colours and though the semen samples from them varied in intensity of melanizing activity, no definite correlation between coat colour and the intensity of activity could be found. Beatty (1961) observed some exceptions to the correlation between the depth of the coat colour and the intensity of the melanizing activity of the semen of rabbits. The present results, however, are not strictly comparable with those reported by Beatty as the two experiments were not done with the same species of animals having the same genotype. Semen samples with yellow colour showed stronger melanizing activity than samples without the visible yellow pigment. Presence of yellow colour might not be due to the presence of urine in semen as was reported in rabbits by Ghang (1959). In this case samples of semen with yellow colour should be of larger volume than samples without the yellow colour. There was, however, no appreciable difference in the volume of semen with and without yellow colour in the three species of animals studied. White \& Lincoln (1960) observed yellow pigment in semen samples from Friesian bulls. This characteristic of semen behaved like a Mendelian dominant. The yellow pigment was identified as riboflavin. A survey of semen pigmentation in fertile sires in England and Wales during 1958-59, however, showed that in some bulls the yellow colour is not constant (Report of the Production Division, Milk Marketing Board, 1959).

Whatever the cause of the melanizing activity of bull, goat and ram semen may be, the results of the present experiment show that the percentage of living (unstained) spermatozoa at various levels of temperature shock in semen is less in the strong than in the weak melanizing group. The proportion of living spermatozoa is directly related to the metabolic activity of semen, and indirectly to its fertilizing capacity and resistance to cold shock (Bishop \& Hancock, 1955). It seems, therefore, that with the melanizing activity of semen are associated the metabolic activity, the fertilizing capacity and the resistance of spermatozoa to cold shock. Metabolic activity of goat spermatozoa as determined by 'fructolysis index' was found to be less in semen with strong melanizing activity than in semen with weak or without melanizing activity (unpublished). It appears that the melanizing activity of semen may be worth considering when the semen of farm animals is used for artificial insemination and/or for the study of metabolic activity of spermatozoa.

\section{AGKNOWLEDGMENTS}

The author is indebted to the Director, Dr H. D. Srivastava, and Dr S. S. Prabhu, Head of the Animal Genetics Division, Indian Veterinary Research Institute, Izatnagar, for facilities and helpful interest in this work.

The author is greatly indebted to Dr R. A. Beatty, Agriculture Research Council Unit of Animal Genetics, Edinburgh, for helpful suggestions and to $\mathrm{Mr}$ R. S. Ganesan for his advice on statistical points. 


\section{REFERENCES}

Beatty, R. A. (1956) Melanizing activity of semen from rabbit males of different genotype. Proc. roy. phys. Soc. Edinb. 25, 39.

Beatty, R. A. (1961) Genetics of mammalian gametes. Anim. Breed. Abstr. 29, 243.

Bishop, M. W. H. \& Hancock, J. L. (1955) The evaluation of bull semen. Vet. Rec. 67, 363.

Chang, M. C. (1959) Fertilizing capacity of spermatozoa. Recent Progress in the Endocrinology of Reproduction, p. 131. Academic Press, New York.

Hancock, J. L. (1951) A staining technique for the study of temperature shock in semen. Nature, Lond. 67, 323.

Kaura, R. L. (1957) Indian breeds of livestock, pp. 7 and 36. Prem Publisher, Lucknow.

Mukherjee, D. P. \& DotT, H. M. (1960) Effects of egg-yolk citrate and egg-yolk glycine diluters on the morphology of bovine spermatozoa. 7 . agric. Sci. 55, 225.

White, I. G. \& Lincoln, G. J. (1960) The yellow pigmentation of bull semen and its content of riboflavin, niacin, thiamine and related compounds. Biochem. 7. 76, 301. 